\title{
Effects of dietary energy and crude protein levels on growth performance, blood profiles, and carcass traits in growing-finishing pigs
}

\author{
Lin Hu Fang ${ }^{1}$, Ying Hai Jin², Sung Ho Do ${ }^{1}$, Jin Su Hong ${ }^{1}$, Byung Ock Kim${ }^{1}$, Tae Hee Han ${ }^{1}$ and \\ Yoo Yong Kim ${ }^{1 *}$
}

${ }^{1}$ School of Agricultural Biotechnology, and Research Institute of Agriculture and Life Sciences, Seoul National University, Seoul 08826, Korea ${ }^{2}$ Department of Animal Science, Yanbian University, Yan Ji, Ji Lin 133000, China

\section{Abstract}

This experiment was conducted to evaluate the effect of dietary energy and crude protein (CP) levels on growth performance, blood profiles, and carcass traits in growing-finishing pigs. A total of 180 crossbred pigs ([Yorkshire $\times$ Landrace] $\times$ Duroc) with an average body weight of $30.96 \pm 3.068 \mathrm{~kg}$ were used for a 12-week feeding trial. Experimental pigs were allotted to a $2 \times 3$ factorial arrangement using a randomized complete block (RCB) design. The first factor was two levels of dietary metabolizable energy (ME) density $(13.40 \mathrm{MJ} / \mathrm{kg}$ or $13.82 \mathrm{MJ} / \mathrm{kg}$ ), and the second factor was three dietary CP levels based on subdivision of growing-finishing phases (high: 18\%/16.3\%/16.3\%/13.2\% middle: 17\%/15.3\%/15.3\%/12.2\% and low: 16\%/14.3\%/14.3\%/11.2\%). Average daily gain (ADG) and gain-feed ratio (G:F ratio) decreased as dietary CP level was decreased linearly (linear, $p<0.05 ; p<0.05$, respectively) in the early growing period, and $\mathrm{G}: \mathrm{F}$ ration also decreased as dietary CP level was decreased linearly (linearly, $p<0.05$ ) over the whole growing phase. Over the entire experimental period, G:F ratio decreased as dietary ME level decreased $(p=0.01)$. Blood urea nitrogen $(\mathrm{BUN})$ concentration was increased as dietary energy level decreased in growing period $(p<0.01)$. During finishing period, total protein concentration was decreased by lower dietary energy level $(p<0.05)$. In this study, there were no significant differences in proximate factors, physiochemical properties, muscle TBARS assay results, $\mathrm{pH}$ changes, or color of pork by dietary treatments. However, saturated fatty acid (SFA) increased $(p<0.01)$ and polyunsaturated fatty acid (PUFA) decreased $(p<0.05)$ when ME was decreased by $0.42 \mathrm{MJ} / \mathrm{kg}$ in growing-finishing pig diets. In addition, monounsaturated fatty acid (MUFA) tended to increase when CP level was decreased in growing-finishing pig diets $(p=0.06)$. A growing-finishing diet of $13.82 \mathrm{MJ} / \mathrm{kg}$ diet of ME with the high CP level can improve growth performance and show better fatty acids composition of pork.

Keywords: Energy, Crude protein, Growth performance, Blood profiles, Carcass traits, Growing-finishing pigs

\section{Background}

Supplying adequate nutrients has been noted as the most important factor in pig production in the swine industry. Several studies have reported that insufficient nutrients can limit the growth potential of animals, while excessive nutrients can increase economic profitability but cause environmental pollution [1-3]. Nieto et al. [4] demonstrated that growth was based on the deposition of proteins

Received: May 14,2019 Revised: Jun 11, 2019 Accepted: Jun 11,2019

"Corresponding author: Yoo Yong Kim, School of Agricultural Biotechnology, and Research Institute of Agriculture and Life Sciences, Seoul National University, Seoul 08826, Korea.

Tel: +82-2-880-4801, E-mail: yooykim@snu.ac.kr

This is an Open Access article distributed under the terms of the Creative Commons Attribution Non-Commercial License (http://creativecommons.org/licenses/bync/4.0/) which permits unrestricted non-commercial use, distribution, and reproduction in any medium, provided the original work is properly cited.

Copyright (C) 2019 Korean Society of Animal Science and Technology. 
and lipids in pigs. Therefore, dietary energy and crude protein (CP) levels play a major role in growth performance.

Nutrient requirements defined by the NRC were revised from 1998 to 2012 [5,6], especially protein. NRC 2012 recommends a lower CP level (CP calculated from N by multiplying by 100/16 or 6.25) than NRC 1998 in growing-finishing pigs (NRC 1998: 18\%-13.2\%; NRC 2012: 15.7\%-10.4\%).

Insufficient nutrients or excessive nutrients may reduce growth production in swine [7-10]. Pigs fed a low-energy diet had decreased total energy intake and growth performance [11-13] while excessive intake of $\mathrm{CP}$ increased $\mathrm{N}$ excretion [7-9]. Using low$\mathrm{CP}$ diets can reduce feed costs, $\mathrm{N}$ excretion, and plasma urea $\mathrm{N}$ in swine $[14,15]$.

Whittemore [16] showed that the pigs had the highest weight gain in the growing period, and fat deposition was greater than protein deposition in the finishing period. The most important factor to maximize muscle development in growing pigs is to provide optimal protein and amino acid levels [17]. However, finishing feeds need to be formulated keeping fat deposition in mind, as this can affect carcass fatness and pork quality [18].

This experiment was conducted to evaluate the effects of subdivision of the growing-finishing phases with different dietary protein levels and different dietary energy densities on growth performance, blood profiles, and pork quality.

\section{Materials and Method}

\section{Experimental animals and management}

All experimental procedures involving animals were conducted in accordance with the Animal Experimental Guidelines provided by the Seoul National University Institutional Animal Care and Use Committee (SNUIACUC; SNU-160819-9). A total of 180 crossbred pigs ([Yorkshire $\times$ Landrace $] \times$ Duroc) with an average body weight (BW) of $30.96 \pm 3.068 \mathrm{~kg}$ were used for a 12-week feeding trial. Pigs were reared at the Seoul National University experimental farm. Three male pigs and three female pigs were assigned to each pen of a growing facility based on BW, and pigs in each pen were maintained until the end of experiment. Pigs were randomly

Table 1. Formula and chemical compositions of diets in early growing pigs

\begin{tabular}{|c|c|c|c|c|c|c|}
\hline \multirow{2}{*}{$\begin{array}{l}\text { Energy } \\
\text { CP (\%) }\end{array}$} & \multicolumn{3}{|c|}{ ME $13.40 \mathrm{MJ} / \mathrm{kg}$} & \multicolumn{3}{|c|}{ ME $13.82 \mathrm{MJ} / \mathrm{kg}$} \\
\hline & High & Middle & Low & High & Middle & Low \\
\hline Total & 100.00 & 100.00 & 100.00 & 100.00 & 100.00 & 100.00 \\
\hline \multicolumn{7}{|l|}{ Ingredient (\%) } \\
\hline Corn & 66.55 & 69.27 & 71.85 & 63.53 & 66.59 & 69.60 \\
\hline Soybean meal & 23.10 & 20.30 & 17.53 & 23.50 & 20.74 & 18.02 \\
\hline Wheat bran & 3.99 & 4.01 & 4.02 & 3.99 & 3.96 & 3.98 \\
\hline Palm kernel meal & 3.04 & 3.05 & 3.04 & 3.07 & 3.03 & 3.04 \\
\hline Tallow & 1.18 & 1.11 & 1.05 & 3.50 & 3.44 & 3.37 \\
\hline Mono-dicalcium phosphate & 2.50 & 2.52 & 2.56 & 2.50 & 2.55 & 2.55 \\
\hline Limestone & 0.31 & 0.30 & 0.29 & 0.30 & 0.30 & 0.31 \\
\hline L-Lysine-HCl (78\%) & 0.03 & 0.12 & 0.21 & 0.02 & 0.11 & 0.20 \\
\hline DL-Methionine (99\%) & 0.01 & 0.02 & 0.03 & 0.01 & 0.02 & 0.03 \\
\hline Vit. Mix ${ }^{1)}$ & 0.10 & 0.10 & 0.10 & 0.10 & 0.10 & 0.10 \\
\hline Min. $\operatorname{Mix}^{2}$ & 0.10 & 0.10 & 0.10 & 0.10 & 0.10 & 0.10 \\
\hline Salt & 0.30 & 0.30 & 0.30 & 0.30 & 0.30 & 0.30 \\
\hline \multicolumn{7}{|l|}{ Chemical composition ${ }^{3)}$} \\
\hline Metabolizable energy (MJ/kg) & 13.40 & 13.40 & 13.40 & 13.82 & 13.82 & 13.82 \\
\hline Crude protein (\%) & 16.30 & 15.30 & 14.30 & 16.30 & 15.30 & 14.30 \\
\hline Total lysine (\%) & 0.95 & 0.95 & 0.95 & 0.95 & 0.95 & 0.95 \\
\hline Total methionine (\%) & 0.27 & 0.27 & 0.27 & 0.27 & 0.27 & 0.27 \\
\hline Calcium (\%) & 0.66 & 0.66 & 0.66 & 0.66 & 0.66 & 0.66 \\
\hline Total phosphorus (\%) & 0.56 & 0.56 & 0.56 & 0.56 & 0.56 & 0.56 \\
\hline \multicolumn{7}{|c|}{$\begin{array}{l}\text { 1)Provided per kg of diet. Vitamins per kg of complete diets: vitamin A, 8,000 IU; vitamin } \mathrm{D}_{3}, 1,800 \mathrm{IU} \text {; vitamin E, } 60 \mathrm{IU} \text {; vitamin } \mathrm{K}_{3}, 2 \mathrm{mg} \text {; thiamine, } 2.00 \mathrm{mg} \text {; riboflavin, } 7.0 \mathrm{mg} \text {; } \\
\text { pantothenic acid, } 25 \mathrm{mg} \text {; niacin, } 27 \mathrm{mg} \text {; pyridoxine, } 3 \mathrm{mg} \text {; d-biotin, } 0.2 \mathrm{mg} \text {; folic acid, } 1 \mathrm{mg} \text {; vitamin } \mathrm{B}_{12}, 0.03 \mathrm{mg} \text {. }\end{array}$} \\
\hline \multicolumn{7}{|c|}{ 2)Provided per kg of diet. Minerals per kg of complete diet: Se, $0.3 \mathrm{mg} ; \mathrm{l}, 1 \mathrm{mg} ; \mathrm{Mn}, 51.6 \mathrm{mg} ; \mathrm{Cu}, 105 \mathrm{mg} ; \mathrm{Fe}, 150 \mathrm{mg} ; \mathrm{Zn}, 72 \mathrm{mg}$; Co, $0.5 \mathrm{mg}$. } \\
\hline 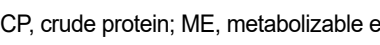 & & & & & & \\
\hline
\end{tabular}


allotted to their respective treatments by an experimental animal allotment program [19]. Pigs were reared in growing-finishing $(2.60 \times 2.84 \mathrm{~m})$ facilities for 12 weeks. Feed and water were provided ad libitum during the entire experimental period by a 6-hole stainless feeder and two nipples installed in each pen.

\section{Experimental design and diet}

Experimental pigs were allotted to a $2 \times 3$ factorial arrangement in randomized complete block (RCB) design. The first factor was two levels of dietary metabolizable energy (ME) density (13.40 $\mathrm{MJ} / \mathrm{kg}$ or $13.82 \mathrm{MJ} / \mathrm{kg}$ ) and the second factor was three dietary $\mathrm{CP}$ levels based on subdivision of growing-finishing phases (high: 18\%/16.3\%/16.3\%/13.2\% middle: $17 \% / 15.3 \% / 15.3 \% / 12.2 \%$ and low: $16 \% / 14.3 \% / 14.3 \% / 11.2 \%)$.

Experimental diets were formulated for four phases: the early growing phase (0-3 weeks), the late growing phase (4-6 weeks), the early finishing phase (7-9 weeks), and the late finishing phase (10-12 weeks). All nutrients in the experimental diets except ME and $\mathrm{CP}$ were met or exceeded the nutrient requirements of the
Dietary energy and crude protein on growth and carcass in pigs

NRC [5]. Formula and chemical compositions of the experimental diets are provided in Tables 1,2,3, and 4.

\section{Growth performance}

Body weight and feed consumption were recorded at 0, 3, 6, 9, and 12 weeks to calculate average daily gain (ADG), average daily feed intake (ADFI), and gain to feed ratio (G:F ratio).

\section{Blood analysis}

Blood samples were taken from the jugular vein of six randomly selected pigs in each treatment to measure blood urea nitrogen (BUN), glucose, and total protein during growing and finishing phages. All blood samples were collected in serum tubes (SST ${ }^{\mathrm{TM}}$ II Advance, BD Vacutainer ${ }^{\circledR}$, Becton Dickinson, Plymouth, UK). Collected blood samples were centrifuged for $15 \mathrm{~min}$ at 6,048 $\times$ $\mathrm{g}$ at $4^{\circ} \mathrm{C}(5810 \mathrm{R}$, Eppendorf, Hamburg, Germany). Serum was carefully transferred to $1.5 \mathrm{~mL}$ plastic tubes and stored at $-20^{\circ} \mathrm{C}$ until analysis. BUN (kinetic UV assay, Roche, Germany) and glucose (enzymatic kinetic assay, Roche, Germany) concentrations

Table 2. Formula and chemical compositions of the diets of late growing pigs

\begin{tabular}{|c|c|c|c|c|c|c|}
\hline \multirow{2}{*}{ Energy } & \multicolumn{3}{|c|}{ ME $13.40 \mathrm{MJ} / \mathrm{kg}$} & \multicolumn{3}{|c|}{ ME 13.82 MJ/kg } \\
\hline & High & Middle & Low & High & Middle & Low \\
\hline Total & 100.00 & 100.00 & 100.00 & 100.00 & 100.00 & 100.00 \\
\hline \multicolumn{7}{|l|}{ Ingredient (\%) } \\
\hline Corn & 66.09 & 68.86 & 71.62 & 63.37 & 66.11 & 68.92 \\
\hline Soybean meal & 22.74 & 20.00 & 17.24 & 23.17 & 20.42 & 17.63 \\
\hline Wheat bran & 3.97 & 3.99 & 4.03 & 4.00 & 4.00 & 3.98 \\
\hline Palm kernel meal & 3.11 & 2.99 & 2.89 & 3.06 & 3.01 & 2.95 \\
\hline Tallow & 0.83 & 0.76 & 0.69 & 3.15 & 3.08 & 3.00 \\
\hline Mono-dicalcium phosphate & 2.30 & 2.35 & 2.39 & 2.32 & 2.35 & 2.38 \\
\hline Limestone & 0.24 & 0.23 & 0.22 & 0.22 & 0.22 & 0.22 \\
\hline L-Lysine-HCl (78\%) & 0.19 & 0.28 & 0.37 & 0.18 & 0.27 & 0.37 \\
\hline DL-Methionine (99\%) & 0.03 & 0.04 & 0.05 & 0.03 & 0.04 & 0.05 \\
\hline Vit. Mix ${ }^{1)}$ & 0.10 & 0.10 & 0.10 & 0.10 & 0.10 & 0.10 \\
\hline Min. Mix $^{2)}$ & 0.10 & 0.10 & 0.10 & 0.10 & 0.10 & 0.10 \\
\hline Salt & 0.30 & 0.30 & 0.30 & 0.30 & 0.30 & 0.30 \\
\hline \multicolumn{7}{|l|}{ Chemical composition ${ }^{3)}$} \\
\hline Metabolizable energy (MJ/kg) & 13.40 & 13.40 & 13.40 & 13.82 & 13.82 & 13.82 \\
\hline Crude protein (\%) & 16.30 & 15.30 & 14.30 & 16.30 & 15.30 & 14.30 \\
\hline Total lysine (\%) & 0.95 & 0.95 & 0.95 & 0.95 & 0.95 & 0.95 \\
\hline Total methionine (\%) & 0.27 & 0.27 & 0.27 & 0.27 & 0.27 & 0.27 \\
\hline Calcium (\%) & 0.59 & 0.59 & 0.59 & 0.59 & 0.59 & 0.59 \\
\hline Total phosphorus (\%) & 0.52 & 0.52 & 0.52 & 0.52 & 0.52 & 0.52 \\
\hline \multicolumn{7}{|c|}{$\begin{array}{l}\text { 1) Provided per kg of diet. Vitamins per } \mathrm{kg} \text { of complete diets: vitamin } \mathrm{A}, 8,000 \mathrm{IU} \text {; vitamin } \mathrm{D}_{3}, 1,800 \mathrm{IU} \text {; vitamin } \mathrm{E} \text {, } \\
\text { pantothenic acid, } 25 \mathrm{mg} \text {; niacin, } 27 \mathrm{mg} \text {; pyridoxine, } 3 \mathrm{mg} \text {; d-biotin, } 0.2 \mathrm{mg} \text {; folic acid, } 1 \mathrm{mg} \text {; vitamin } \mathrm{B}_{12}, 0.03 \mathrm{mg} \text {. }\end{array}$} \\
\hline \multicolumn{7}{|c|}{${ }^{2)}$ Provided per kg of diet. Minerals per kg of complete diet: Se, 0.3 mg; I, 1 mg; Mn, 51.6 mg; Cu, 105 mg; Fe, 150 mg; Zn, 72 mg; Co, 0.5 mg. } \\
\hline
\end{tabular}


Table 3. Formula and chemical compositions of the diets of early finishing pigs

\begin{tabular}{|c|c|c|c|c|c|c|}
\hline \multirow{2}{*}{$\begin{array}{l}\text { Energy } \\
\text { CP (\%) }\end{array}$} & \multicolumn{3}{|c|}{ ME $13.40 \mathrm{MJ} / \mathrm{kg}$} & \multicolumn{3}{|c|}{ ME $13.82 \mathrm{MJ} / \mathrm{kg}$} \\
\hline & High & Middle & Low & High & Middle & Low \\
\hline Total & 100.00 & 100.00 & 100.00 & 100.00 & 100.00 & 100.00 \\
\hline \multicolumn{7}{|l|}{ Ingredient (\%) } \\
\hline Corn & 69.15 & 71.87 & 74.45 & 66.13 & 69.19 & 72.20 \\
\hline Soybean meal & 20.50 & 17.70 & 14.93 & 20.90 & 18.14 & 15.42 \\
\hline Wheat bran & 3.99 & 3.97 & 4.22 & 3.99 & 3.95 & 3.90 \\
\hline Palm kernel meal & 3.03 & 3.05 & 2.86 & 3.29 & 3.01 & 2.73 \\
\hline Tallow & 0.62 & 0.55 & 0.53 & 2.99 & 2.86 & 2.75 \\
\hline Mono-dicalcium phosphate & 2.05 & 2.05 & 2.10 & 2.05 & 2.05 & 2.10 \\
\hline Limestone & 0.15 & 0.18 & 0.18 & 0.15 & 0.18 & 0.18 \\
\hline L-Lysine-HCl (78\%) & 0.01 & 0.11 & 0.20 & 0.00 & 0.10 & 0.19 \\
\hline DL-Methionine (99\%) & 0.00 & 0.02 & 0.03 & 0.00 & 0.02 & 0.03 \\
\hline Vit. Mix ${ }^{1)}$ & 0.10 & 0.10 & 0.10 & 0.10 & 0.10 & 0.10 \\
\hline Min. $\operatorname{Mix}^{2)}$ & 0.10 & 0.10 & 0.10 & 0.10 & 0.10 & 0.10 \\
\hline Salt & 0.30 & 0.30 & 0.30 & 0.30 & 0.30 & 0.30 \\
\hline \multicolumn{7}{|l|}{ Chemical composition ${ }^{3)}$} \\
\hline Metabolizable energy (MJ/kg) & 13.40 & 13.40 & 13.40 & 13.82 & 13.82 & 13.82 \\
\hline Crude protein (\%) & 15.30 & 14.30 & 13.30 & 15.30 & 14.30 & 13.30 \\
\hline Total lysine (\%) & 0.82 & 0.82 & 0.82 & 0.82 & 0.82 & 0.82 \\
\hline Total methionine (\%) & 0.25 & 0.25 & 0.25 & 0.25 & 0.25 & 0.25 \\
\hline Calcium (\%) & 0.52 & 0.52 & 0.52 & 0.52 & 0.52 & 0.52 \\
\hline Total phosphorus (\%) & 0.47 & 0.47 & 0.47 & 0.47 & 0.47 & 0.47 \\
\hline
\end{tabular}

${ }^{1)}$ Provided per kg of diet. Vitamins per kg of complete diets: vitamin $\mathrm{A}, 8,000 \mathrm{IU}$; vitamin $\mathrm{D}_{3}, 1,800 \mathrm{IU}$; vitamin $\mathrm{E}, 60 \mathrm{IU}$; vitamin $\mathrm{K}_{3}, 2 \mathrm{mg}$; thiamine, $2.00 \mathrm{mg}$; riboflavin, $7.0 \mathrm{mg}$; pantothenic acid, $25 \mathrm{mg}$; niacin, $27 \mathrm{mg}$; pyridoxine, $3 \mathrm{mg}$; d-biotin, $0.2 \mathrm{mg}$; folic acid, $1 \mathrm{mg}$; vitamin $\mathrm{B}_{12}, 0.03 \mathrm{mg}$.

${ }^{2)}$ Provided per kg of diet. Minerals per kg of complete diet: Se, 0.15 mg; l, 0.3 mg; Mn, 37 mg; Cu, 11 mg; Fe, 150 mg; Zn, 85 mg; Co, 2 mg.

${ }^{3)}$ Calculated value.

$\mathrm{CP}$, crude protein; ME, metabolizable energy.

were analyzed using a blood analyzer. Total protein concentration was measured by a kinetic colorimetry assay using a blood analyzer (Modular analytics, PE, Roche, Germany).

\section{Carcass traits}

At the end of experiment, four pigs from each treatment group were selected and slaughtered at average $113.42 \mathrm{~kg} \pm 1.307$ for carcass analysis. Pork samples were collected nearby the 10th rib on the right side of the carcass. After chilling, 30 minutes after slaughter was regarded as the initial time. The $\mathrm{pH}$ was measured at $0,3,6,12$, and 24 hours and the color of the longissimus muscle was measured at the initial time and 24 hours later. The pork samples were always stored in the freezer $\left(4^{\circ} \mathrm{C}\right)$. The $\mathrm{pH}$ was measured using a $\mathrm{pH}$ meter (Model 720, Thermo Orion, Fullerton, CA, USA) and pork color was measured by CIE color $\mathrm{L}^{*}, \mathrm{a}^{*}$, and $\mathrm{b}^{*}$ values using a CR300 (Minolta Camera Co., Osaka, Japan). Chemical analysis of pork samples was conducted using the AOAC method [20].

Water holding capacity of pork was measured by the centrifuge method. Longissimus muscles were ground and sampled in a filter tube, then heated in water bath at $80^{\circ} \mathrm{C}$ for $20 \mathrm{~min}$ and centrifuged for $10 \mathrm{~min}$ at $2,688 \times \mathrm{g}$ at $10^{\circ} \mathrm{C}$ (5810R, Eppendorf, Hamburg, Germany). To calculate cooking loss, longissimus muscles were packed in a polyethylene bag that was then heated in a water bath until the core temperature reached $72{ }^{\circ} \mathrm{C}$ and weighed before and after cooking. After heating, samples were cored ( 0.5 inch in diameter) parallel to the muscle fiber and the cores were used to measure shear force using a salter (Warner Barzler Shear, Norwood, MA, USA). Cooking loss, shear force, and water holding capacity of pork were analyzed by the Animal Origin Food Science laboratory, Seoul National University.

Lipids in pork samples were extracted from duplicate $10 \mathrm{~g}$ samples with chloroform: methanol $(2.1, \mathrm{v} / \mathrm{v})[21]$ on a shaking incubator $\left(25^{\circ} \mathrm{C}, 8.064 \times \mathrm{g}\right)$ for 24 hours. Extracted lipids were filtered with filter paper (Whatman TM No.4, Buckinghamshire, UK). Twenty-five milliliters of $0.88 \% \mathrm{NaCl}$ was added to the filtered sample, which was then centrifuged at 2,090 $\times \mathrm{g}$ for $10 \mathrm{~min}$ (Continent 512R, Hanil Co., Ltd., Incheon, Korea). The supernatant 
Table 4. Formula and chemical compositions of the diets of late finishing pigs

\begin{tabular}{|c|c|c|c|c|c|c|}
\hline \multirow{2}{*}{$\begin{array}{l}\text { Energy } \\
\mathrm{CP}(\%)\end{array}$} & \multicolumn{3}{|c|}{ ME $13.40 \mathrm{MJ} / \mathrm{kg}$} & \multicolumn{3}{|c|}{ ME $13.82 \mathrm{MJ} / \mathrm{kg}$} \\
\hline & High & Middle & Low & High & Middle & Low \\
\hline Total & 100.00 & 100.00 & 100.00 & 100.00 & 100.00 & 100.00 \\
\hline \multicolumn{7}{|l|}{ Ingredient (\%) } \\
\hline Corn & 75.13 & 77.74 & 80.44 & 72.13 & 75.06 & 78.12 \\
\hline Soybean meal & 15.10 & 12.33 & 9.56 & 15.50 & 12.77 & 10.03 \\
\hline Wheat bran & 3.97 & 4.00 & 4.02 & 3.92 & 3.99 & 4.04 \\
\hline Palm kernel meal & 3.02 & 3.02 & 3.03 & 3.30 & 2.97 & 2.63 \\
\hline Tallow & 0.28 & 0.24 & 0.18 & 2.65 & 2.56 & 2.42 \\
\hline Mono-dicalcium phosphate & 1.85 & 1.90 & 1.90 & 1.85 & 1.90 & 1.90 \\
\hline Limestone & 0.14 & 0.15 & 0.16 & 0.15 & 0.15 & 0.15 \\
\hline L-Lysine-HCl (78\%) & 0.01 & 0.10 & 0.19 & 0.00 & 0.09 & 0.18 \\
\hline DL-Methionine (99\%) & 0.00 & 0.01 & 0.02 & 0.00 & 0.01 & 0.03 \\
\hline Vit. Mix ${ }^{1)}$ & 0.10 & 0.10 & 0.10 & 0.10 & 0.10 & 0.10 \\
\hline Min. Mix $^{2)}$ & 0.10 & 0.10 & 0.10 & 0.10 & 0.10 & 0.10 \\
\hline Salt & 0.30 & 0.30 & 0.30 & 0.30 & 0.30 & 0.30 \\
\hline \multicolumn{7}{|l|}{ Chemical composition ${ }^{3)}$} \\
\hline Metabolizable energy (MJ/kg) & 13.40 & 13.40 & 13.40 & 13.82 & 13.82 & 13.82 \\
\hline Crude protein (\%) & 13.20 & 12.20 & 11.20 & 13.20 & 12.20 & 11.20 \\
\hline Total lysine (\%) & 0.60 & 0.60 & 0.60 & 0.60 & 0.60 & 0.60 \\
\hline Total methionine (\%) & 0.21 & 0.21 & 0.21 & 0.21 & 0.21 & 0.21 \\
\hline Calcium (\%) & 0.46 & 0.46 & 0.46 & 0.46 & 0.46 & 0.46 \\
\hline Total phosphorus (\%) & 0.43 & 0.43 & 0.43 & 0.43 & 0.43 & 0.43 \\
\hline
\end{tabular}

${ }^{1)}$ Provided per kg of diet. Vitamins per kg of complete diets: vitamin A, 8,000 IU; vitamin $\mathrm{D}_{3}, 1,800 \mathrm{IU}$; vitamin E, $60 \mathrm{IU}$; vitamin $\mathrm{K}_{3}, 2 \mathrm{mg}$; thiamine, $2.00 \mathrm{mg}$; riboflavin, $7.0 \mathrm{mg}$; pantothenic acid, $25 \mathrm{mg}$; niacin, $27 \mathrm{mg}$; pyridoxine, $3 \mathrm{mg}$; d-biotin, $0.2 \mathrm{mg}$; folic acid, $1 \mathrm{mg}$; vitamin $\mathrm{B}_{12}, 0.03 \mathrm{mg}$.

${ }^{2)}$ Provided per kg of diet. Minerals per kg of complete diet: Se, 0.15 mg; I, 0.3 mg; Mn, 37 mg; Cu, 11 mg; Fe, 150 mg; Zn, 85 mg; Co, 2 mg.

${ }^{3)}$ Calculated value.

$\mathrm{CP}$, crude protein; ME, metabolizable energy.

was separated and pork lipids were concentrated using $\mathrm{N}_{2}$ gas at $45^{\circ} \mathrm{C}$. After concentrating the lipids, $0.1 \mathrm{~g}$ of lipids was transferred to a $15 \mathrm{~mL}$ tube with $1 \mathrm{~mL}$ of internal standard ( $1 \mathrm{mg}$ of undecanoic acid in $1 \mathrm{~mL}$ of iso-octane) and $1.5 \mathrm{~mL}$ of $0.5 \mathrm{~N}$ methanolic $\mathrm{NaOH}$. Samples were heated in a water bath at $85^{\circ} \mathrm{C}$ for $10 \mathrm{~min}$ and cooled to room temperature. After cooling, $2 \mathrm{~mL}$ of $14 \%$ $\mathrm{BF}_{3}$-methanol was added and then the heating process was repeated one more time. Then, $2 \mathrm{~mL}$ of iso-octane and $1 \mathrm{~mL}$ saturated $\mathrm{NaCl}$ were added, and the sample was centrifuged at 4,200 $\times \mathrm{g}$ for 3 min (Continent 512R, Hanil Co., Ltd., Incheon, Korea). Upper layer containing fatty acid methyl esters (FAMEs) was dehydrated with anhydrous sodium sulfate and transferred to a vial. The sample in the vial was analyzed using a gas chromatograph (HP 7890, Agilent Technologies, Santa Clara, CA, USA) with a split ratio of 50:1. A capillary column (DB-23, $60 \mathrm{~m} \times 250 \mu \mathrm{m} \times 0.25 \mu \mathrm{m}$, Agilent, Santa Clara, CA, USA) was used. The injector and detector temperatures were maintained at $250^{\circ} \mathrm{C}$ and $280^{\circ} \mathrm{C}$, respectively. Column oven temperature was varied as follows: $50^{\circ} \mathrm{C}$ for $1 \mathrm{~min}$, increased to $130^{\circ} \mathrm{C}$ at $25^{\circ} \mathrm{C} / \mathrm{min}, 170^{\circ} \mathrm{C}$ at $8^{\circ} \mathrm{C} / \mathrm{min}$, then held at $215^{\circ} \mathrm{C}$ after increasing to this this temperature at $1.5^{\circ} \mathrm{C} / \mathrm{min}$. Nitrogen was used as a carrier gas at linear flow of $4 \mathrm{~mL} / \mathrm{min}$. Individual FAMEs were identified by comparison of relative retention times of peaks from samples with those of external standards (37 FAME mix and CLA mix, Supelco, Bellefonte, PA, USA) calculated based on the Korean Food Standards Codex (MFDS, 2017).

\section{Statistical analysis}

Data for the various groups were compared by least squares mean comparisons and evaluated using general linear models (GLMs) in SAS (SAS Institute Inc., Cary, NC, USA). Every pen was used as one unit in the feeding trial, and individual pigs were considered experimental units with regard to analysis of blood profiles and carcass qualities. Orthogonal polynomial contrasts were used to detect linear and quadratic responses to $\mathrm{CP}$ levels when the significance of the $\mathrm{CP}$ effect was evaluated. The treatment effect was considered to be significant if $p<0.01$ or $p<0.05$ while $0.05<p$ and $p<0.10$ was considered to indicated a trend in the treatment effect. 


\section{Results and Discussion}

\section{Growth performance}

The effect of dietary energy and CP levels on growth performance are presented in Table 5. Average daily gain and G:F ratio decreased linearly as dietary CP level was decreased (linear, $p<0.05$; $p<0.05$, respectively) in the early growing phase, and G:F ratio decreased linearly as dietary CP level was decreased (linear, $p<0.05$ ) over the entire growing phase. In the growing period, pigs showed the highest weight gain due to muscle development [16]. Dietary $\mathrm{CP}$ and amino acid levels affect protein deposition [16,22]. Several studies have demonstrated that ADG and G:F ratio decreased as
CP level increased in the growing phase [10,23]. In this study, dietary energy density did not have any significant effect on growth performance during the growing period, consistent with the study of Kil and colleagues [24].

Dietary energy and protein levels did not differ significantly among groups in the finishing period. Similar to our findings, Kerr et al. [10] represented that a $0.42 \mathrm{MJ}$ decrease in NE/ $\mathrm{kg}$ and $4 \% \mathrm{CP}$ in $88.3-109.7 \mathrm{~kg}$ pigs did not significantly affect growth performance. Kil et al. [24] reported that a $1.26 \mathrm{MJ} / \mathrm{kg}$ decrease in $\mathrm{ME}$ in the finishing pig diet had no effect on growth performance.

However, G:F ratio decreased when dietary ME level was decreased $(p=0.01)$. Furthermore, BW and ADG showed significant

Table 5. Effects of dietary energy and crude protein levels on growth performance in growing-finishing pigs

\begin{tabular}{|c|c|c|c|c|c|c|c|c|c|c|}
\hline \multirow{2}{*}{$\begin{array}{l}\text { Energy } \\
\text { CP (\%) }\end{array}$} & \multicolumn{3}{|c|}{ ME $13.40 \mathrm{MJ} / \mathrm{kg}$} & \multicolumn{3}{|c|}{ ME $13.82 \mathrm{MJ} / \mathrm{kg}$} & \multirow{2}{*}{ SEM } & \multicolumn{3}{|c|}{$p$-value } \\
\hline & High & Middle & Low & High & Middle & Low & & ME & $\mathrm{CP}$ & $\mathrm{M} \times \mathrm{C}$ \\
\hline \multicolumn{11}{|c|}{ Body weight (kg) } \\
\hline Initial & 30.97 & 30.95 & 30.97 & 30.95 & 30.95 & 30.95 & 0.854 & - & - & - \\
\hline 3 wks & 42.86 & 40.59 & 41.17 & 43.48 & 42.73 & 40.37 & 1.012 & 0.77 & 0.66 & 0.86 \\
\hline 6 wks & 63.03 & 62.26 & 62.64 & 66.92 & 63.66 & 59.77 & 1.369 & 0.78 & 0.57 & 0.63 \\
\hline 9 wks & 80.78 & 83.03 & 82.56 & 87.06 & 84.65 & 78.87 & 1.553 & 0.67 & 0.66 & 0.47 \\
\hline 12 wks & $100.19^{c}$ & $104.10^{b}$ & $102.78^{b}$ & $108.17^{a}$ & $106.05^{\mathrm{ab}}$ & $99.62^{c}$ & 1.602 & 0.50 & 0.61 & 0.40 \\
\hline \multicolumn{11}{|l|}{ ADG (g) } \\
\hline $0-3 w_{k s}^{L}$ & 567 & 459 & 486 & 597 & 561 & 448 & 19.4 & 0.38 & 0.04 & 0.29 \\
\hline $4-6$ wks & 960 & 1,032 & 1,023 & 1,116 & 997 & 924 & 32.2 & 0.91 & 0.73 & 0.28 \\
\hline $0-6$ wks & 763 & 745 & 754 & 857 & 779 & 686 & 18.7 & 0.59 & 0.14 & 0.19 \\
\hline $7-9$ wks & 845 & 989 & 948 & 959 & 1,000 & 910 & 30.9 & 0.66 & 0.50 & 0.62 \\
\hline $10-12$ wks & 924 & 1,003 & 963 & 1,005 & 1,019 & 988 & 16.9 & 0.26 & 0.53 & 0.71 \\
\hline $7-12$ wks & 885 & 996 & 956 & 982 & 1,009 & 949 & 16.1 & 0.27 & 0.19 & 0.37 \\
\hline 0-12 wks & $824^{\mathrm{C}}$ & $871^{b}$ & $855^{\mathrm{bc}}$ & $919^{a}$ & $894^{\mathrm{ab}}$ & $818^{\mathrm{C}}$ & 12.2 & 0.24 & 0.23 & 0.07 \\
\hline \multicolumn{11}{|l|}{ ADFI (g) } \\
\hline $0-3$ wks & 1,462 & 1,366 & 1,434 & 1,390 & 1,450 & 1,340 & 40.1 & 0.75 & 0.93 & 0.66 \\
\hline $4-6$ wks & 2,280 & 2,304 & 2,490 & 2,350 & 2,378 & 2,164 & 12.3 & 0.51 & 0.97 & 0.15 \\
\hline $0-6$ wks & 1,872 & 1,834 & 1,960 & 1,872 & 1,912 & 1,752 & 39.2 & 0.60 & 0.98 & 0.35 \\
\hline $7-9$ wks & 2.674 & 2,770 & 3,032 & 2,786 & 2,798 & 2,620 & 60.2 & 0.46 & 0.81 & 0.19 \\
\hline $10-12$ wks & 3,522 & 3,580 & 3,748 & 3,512 & 3,662 & 3,204 & 72.8 & 0.29 & 0.70 & 0.18 \\
\hline $7-12$ wks & 3,100 & 3,176 & 3,390 & 3,150 & 3,230 & 2,910 & 63.8 & 0.33 & 0.88 & 0.17 \\
\hline $0-12$ wks & 2,486 & 2,506 & 2,674 & 2,512 & 2,570 & 2,334 & 49.6 & 0.42 & 0.94 & 0.22 \\
\hline \multicolumn{11}{|l|}{ G:F ratio } \\
\hline $0-3 w_{k s}^{L}$ & 0.390 & 0.340 & 0.340 & 0.434 & 0.388 & 0.338 & 0.0118 & 0.18 & 0.03 & 0.58 \\
\hline $4-6$ wks & 0.426 & 0.448 & 0.408 & 0.478 & 0.422 & 0.422 & 0.0112 & 0.56 & 0.42 & 0.39 \\
\hline $0-6$ wks $^{\mathrm{L}}$ & 0.416 & 0.406 & 0.382 & 0.456 & 0.408 & 0.390 & 0.0083 & 0.18 & 0.02 & 0.52 \\
\hline $7-9$ wks & 0.316 & 0.362 & 0.314 & 0.344 & 0.358 & 0.350 & 0.0094 & 0.31 & 0.38 & 0.67 \\
\hline $10-12$ wks & 0.266 & 0.280 & 0.256 & 0.290 & 0.278 & 0.328 & 0.0973 & 0.12 & 0.80 & 0.30 \\
\hline $7-12$ wks & 0.286 & 0.314 & 0.284 & 0.312 & 0.312 & 0.336 & 0.0073 & 0.09 & 0.71 & 0.33 \\
\hline $0-12$ wks & 0.334 & 0.350 & 0.322 & 0.368 & 0.348 & 0.356 & 0.0046 & 0.01 & 0.43 & 0.13 \\
\hline
\end{tabular}

Linear response $(p<0.05)$ to dietary CP levels when a significant CP effect was detected.

${ }^{a-c}$ means with different superscripts in the same row differ significantly $(p<0.05)$.

CP, crude protein; ME, metabolizable energy; SEM, standard error of the mean; ADG, average daily gain; ADFI, average daily feed intake. 
differences over the course of the experiment $(p<0.05)$, and 13.82 $\mathrm{MJ} / \mathrm{kg}$ and the high CP level resulted in the highest BW and ADG among the six treatments.

\section{Blood profiles}

The effects of dietary energy and CP levels on blood profiles are presented in Table 6. There were no significant differences in glucose and total protein concentrations when pigs were fed different dietary $\mathrm{ME}$ and $\mathrm{CP}$ levels during the growing period, but BUN concentration increased with a decrease in dietary $\mathrm{ME}(p<0.01)$. In the finishing period, total protein concentration decreased when pigs were fed lower dietary ME concentrations $(p<0.05)$.

Ammonia is produced by the body after eating protein and the liver produces urea as a waste product of protein digestion. Urea nitrogen is a waste product that is released by the liver and then filtered out of the blood by the kidneys $[25,26]$. Therefore, BUN is used as a standard index for evaluating protein quality or excessive protein intake [27,28]. Fuller et al. [29] demonstrated that feeding animals carbohydrates could increase protein deposition. BUN level is affected by $\mathrm{N}$ intake [30], and has a negative correlations with $\mathrm{ADG}$ and G:F ratio [26]. In this study, BUN concentration decreased because pigs were fed more energy, which likely improved protein deposition and utilization.

Suboptimal protein intake can decrease the levels of blood total protein [31]. Matthews et al. [32] represented that total protein concentration increased when protein utilization by pigs was improved. In this experiment showed that total protein concentration decreased as ME level in the diet was decreased during the finishing period. This is consistent with the decrease in the G:F ratio with a decrease in dietary ME.

\section{Carcass traits}

The effect of dietary energy and CP levels on carcass traits are pre- sented in Table 7. In this study, there were no significant differences in moisture, $\mathrm{CP}$, crude fat, or crude ash according to diet. Other studies have reported similar results; Kil et al. [33] showed there was no significant difference in $\mathrm{CP}$ and crude fat in pork when pigs were fed diets with different GE (18.34-16.20 MJ/kg). Stewart et al. [34] showed that adding soybean hulls and wheat middling to 30\% could improve CP levels in growing-finishing pigs (growing diets: 17.83\%-20.30\%; finishing diets: 12.44\%-15.21\%) but this had no significant effects on moisture, $\mathrm{CP}$, crude fat, or crude ash in the resulting pork.

The effect of dietary energy and CP levels on physiochemical properties of the meat are presented in Table 8. Variations in diet had no detrimental effects on cooking loss, shear force, or water holding capacity. These results are consistent with those of Apple et al. [18] who demonstrated that cooking loss was not affected by different levels of ME (14.57-13.82 MJ/kg). Madeira et al. [35] represented that decreasing $\mathrm{CP}$ level in the finishing diet (16\%13\%) had no effect on cooking loss. Additionally, Widmer et al. [36] reported that decreasing $\mathrm{CP}$ in the growing-finishing period by $4 \%$ had no effect on cooking loss. Meng et al. [37] demonstrated that decreasing energy (ME: 14.65-14.24 MJ/kg) and CP levels (growing period: $18 \%-17 \%$ and finishing period: $16 \%-15 \%$ ) had no effects on water holding capacity or cooking loss. Widmer et al. [36] represented that decreasing energy (growing period: $1.68 \mathrm{MJ} /$ $\mathrm{kg}$ of ME and finishing period: $0.82 \mathrm{MJ} / \mathrm{kg}$ of ME) and CP level (growing period: $21.3 \%-15.34 \%$; early finishing period: 18.76\%$15.34 \%$ and late finishing period: $13.64 \%-11.24 \%$ ) had no effects on cooking loss and shear force.

Table 9 shows the effect of energy and CP levels on muscle. TBARS is an index of fat oxidation. Madsen et al. [38] found that the process of fat oxidation could be accelerated in the logissimus by the intake of crude fat. In this study, a decrease in $\mathrm{ME}$ of $0.42 \mathrm{MJ} / \mathrm{kg}$ and in $\mathrm{CP}$ of $2 \%$ had no significant effect on muscle

Table 6. Effects of dietary energy and crude protein levels on blood profiles in growing-finishing pigs

\begin{tabular}{|c|c|c|c|c|c|c|c|c|c|c|}
\hline \multirow{2}{*}{$\begin{array}{l}\text { Energy } \\
\text { CP (\%) }\end{array}$} & \multicolumn{3}{|c|}{ ME $13.40 \mathrm{MJ} / \mathrm{kg}$} & \multicolumn{3}{|c|}{ ME $13.82 \mathrm{MJ} / \mathrm{kg}$} & \multirow{2}{*}{ SEM } & \multicolumn{3}{|c|}{$p$-value } \\
\hline & High & Middle & Low & High & Middle & Low & & ME & $\mathrm{CP}$ & $\mathrm{M} \times \mathrm{C}$ \\
\hline \multicolumn{11}{|c|}{ Blood urea nitrogen $(\mathrm{BUN})(\mathrm{mmol} / \mathrm{L})$} \\
\hline 6 wks & 4.61 & 4.17 & 4.11 & 3.36 & 3.29 & 4.03 & 0.144 & $<0.01$ & 0.71 & 0.31 \\
\hline $12 w_{k s}^{L}$ & 4.92 & 4.03 & 3.83 & 4.41 & 4.81 & 3.46 & 0.187 & 0.93 & 0.07 & 0.28 \\
\hline \multicolumn{11}{|l|}{ Glucose (mmol/L) } \\
\hline 6 wks & 46.26 & 45.12 & 48.48 & 50.33 & 46.18 & 42.28 & 0.662 & 0.37 & 0.27 & 0.26 \\
\hline 12 wks & 42.28 & 46.45 & 45.24 & 45.89 & 46.17 & 48.94 & 0.547 & 0.54 & 0.84 & 0.16 \\
\hline \multicolumn{11}{|l|}{ Total protein (g/L) } \\
\hline 6 wks & 67.51 & 67.30 & 65.32 & 69.18 & 67.31 & 63.71 & 0.743 & 1.00 & 0.10 & 0.65 \\
\hline 12 wks & 67.02 & 65.50 & 67.31 & 70.02 & 69.24 & 68.48 & 0.601 & 0.04 & 0.73 & 0.68 \\
\hline
\end{tabular}

Linear response $(p<0.05)$ to dietary CP levels when a significant CP effect was detected.

$\mathrm{CP}$, crude protein; ME, metabolizable energy; SEM, standard error of the mean; BUN, blood urea nitrogen. 
Table 7. Effect of dietary energy and crude protein levels on proximate analysis of longissimus muscles in growing-finishing pigs

\begin{tabular}{|c|c|c|c|c|c|c|c|c|c|c|}
\hline \multirow{2}{*}{$\begin{array}{l}\text { Energy } \\
\text { CP (\%) }\end{array}$} & \multicolumn{3}{|c|}{ ME $13.40 \mathrm{MJ} / \mathrm{kg}$} & \multicolumn{3}{|c|}{ ME $13.82 \mathrm{MJ} / \mathrm{kg}$} & \multirow{2}{*}{ SEM } & \multicolumn{3}{|c|}{$p$-value } \\
\hline & High & Middle & Low & High & Middle & Low & & ME & $\mathrm{CP}$ & $\mathrm{M} \times \mathrm{C}$ \\
\hline \multicolumn{11}{|c|}{ Proximate analysis (\%) } \\
\hline Moisture & 74.73 & 73.81 & 74.21 & 72.97 & 74.07 & 73.18 & 0.247 & 0.10 & 0.91 & 0.25 \\
\hline Crude ash & 1.19 & 1.29 & 1.15 & 1.07 & 0.95 & 1.21 & 0.720 & 0.16 & 0.99 & 0.15 \\
\hline Crude protein & 23.37 & 23.36 & 22.84 & 23.10 & 23.35 & 23.50 & 0.231 & 0.82 & 0.96 & 0.74 \\
\hline Crude fat & 2.40 & 4.03 & 3.12 & 3.46 & 1.63 & 1.74 & 0.352 & 0.20 & 0.82 & 0.13 \\
\hline
\end{tabular}

$\mathrm{CP}$, crude protein; $\mathrm{ME}$, metabolizable energy; SEM, standard error of the mean.

Table 8. Effect of dietary energy and crude protein levels on physiochemical properties of longissimus muscles from growing-finishing pigs

\begin{tabular}{|c|c|c|c|c|c|c|c|c|c|c|}
\hline \multirow{2}{*}{$\begin{array}{l}\text { Energy } \\
\mathrm{CP}(\%)\end{array}$} & \multicolumn{3}{|c|}{ ME $13.40 \mathrm{MJ} / \mathrm{kg}$} & \multicolumn{3}{|c|}{ ME $13.82 \mathrm{MJ} / \mathrm{kg}$} & \multirow{2}{*}{ SEM } & \multicolumn{3}{|c|}{$p$-value } \\
\hline & High & Middle & Low & High & Middle & Low & & ME & $\mathrm{CP}$ & $M \times C$ \\
\hline \multicolumn{11}{|l|}{ Physiochemical property } \\
\hline WHC $(\%)^{1)}$ & 68.89 & 67.48 & 68.94 & 69.23 & 70.57 & 71.69 & 0.592 & 0.10 & 0.61 & 0.59 \\
\hline Shear force $(\mathrm{kg} / 0.5 \mathrm{inch})$ & 7.59 & 7.23 & 7.45 & 7.64 & 6.94 & 7.34 & 0.261 & 0.84 & 0.75 & 0.97 \\
\hline Cooking loss (\%) & 31.85 & 31.07 & 31.36 & 31.23 & 30.83 & 30.22 & 0.293 & 0.30 & 0.59 & 0.83 \\
\hline
\end{tabular}

${ }^{1)}$ Water holding capacity.

$\mathrm{CP}$, crude protein; ME, metabolizable energy; SEM, standard error of the mean.

Table 9. Effect of dietary energy and crude protein levels on TBARS assay of longissimus muscles from growing-finishing pigs

\begin{tabular}{|c|c|c|c|c|c|c|c|c|c|c|}
\hline \multirow{2}{*}{$\begin{array}{l}\text { Energy } \\
\text { CP (\%) }\end{array}$} & \multicolumn{3}{|c|}{ ME $13.40 \mathrm{MJ} / \mathrm{kg}$} & \multicolumn{3}{|c|}{ ME $13.82 \mathrm{MJ} / \mathrm{kg}$} & \multirow{2}{*}{ SEM } & \multicolumn{3}{|c|}{$p$-value } \\
\hline & High & Middle & Low & High & Middle & Low & & ME & CP & $M \times C$ \\
\hline \multicolumn{11}{|c|}{ TBARS (mgMA/kg) } \\
\hline Day 0 & 0.23 & 0.22 & 0.23 & 0.24 & 0.23 & 0.22 & 0.004 & 0.70 & 0.56 & 0.69 \\
\hline Day 5 & 0.24 & 0.22 & 0.21 & 0.21 & 0.22 & 0.21 & 0.004 & 0.21 & 0.44 & 0.53 \\
\hline Day 7 & 0.57 & 0.56 & 0.57 & 0.56 & 0.55 & 0.55 & 0.007 & 0.50 & 0.97 & 0.93 \\
\hline
\end{tabular}

$\mathrm{CP}$, crude protein; $\mathrm{ME}$, metabolizable energy; SEM, standard error of the mean.

Table 10. Effect of dietary energy and crude protein levels on fatty acid composition of longissimus muscles from growing-finishing pigs

\begin{tabular}{|c|c|c|c|c|c|c|c|c|c|c|}
\hline \multirow{2}{*}{$\begin{array}{l}\text { Energy } \\
\text { CP (\%) }\end{array}$} & \multicolumn{3}{|c|}{ ME $13.40 \mathrm{MJ} / \mathrm{kg}$} & \multicolumn{3}{|c|}{ ME 13.82 MJ/kg } & \multirow{2}{*}{ SEM } & \multicolumn{3}{|c|}{$p$-value } \\
\hline & High & Middle & Low & High & Middle & Low & & ME & CP & $\mathrm{M} \times \mathrm{C}$ \\
\hline \multicolumn{11}{|c|}{ Fatty acid composition (\%) } \\
\hline SFA & 39.08 & 40.69 & 39.67 & 37.75 & 37.24 & 37.39 & 0.427 & $<0.01$ & 0.82 & 0.53 \\
\hline MUFA & 41.37 & 39.14 & 42.23 & 40.86 & 40.46 & 41.77 & 0.366 & 0.86 & 0.06 & 0.47 \\
\hline PUFA & 19.56 & 20.17 & 18.10 & 21.40 & 22.30 & 20.84 & 0.512 & 0.03 & 0.35 & 0.93 \\
\hline
\end{tabular}

$\mathrm{CP}$, crude protein; ME, metabolizable energy; SEM, standard error of the mean; SFA, saturated fatty acids; MUFA, monounsaturated fatty acids; PUFA, polyunsaturated fatty acids.

TBARS assay. Other studies have also reported that a decrease in ME and CP levels had no effects on TBARS assay [35,37].

Table 10 shows the effects of energy and CP levels on fatty acid composition in growing-finishing pig diets. Saturated fatty acid (SFA) increased $(p<0.01)$ and polyunsaturated fatty acid (PUFA) decreased $(p<0.05)$ as ME was decreased by $0.42 \mathrm{MJ} / \mathrm{kg}$ in growing-finishing pig diets. In addition, monounsaturated fatty acid (MUFA) content tended to increase when CP level was de- creased in growing-finishing pig diets $(p=0.06)$. European Food Safe Authority (EFSA) recommend that for food to be considered healthy, it should have a low content of SFA [39]. Feed ingredients and nutrition composition can also affect fatty acid composition in pork [40,41]. Nemechek et al. [42] and Davis et al. [43] demonstrated that SFA content could be decreased and PUFA content could be increased by decreasing tallow levels or decreasing $\mathrm{ME}$ by $0.42 \mathrm{MJ} / \mathrm{kg}(13.82-13.40 \mathrm{MJ} / \mathrm{kg})$ in growing-finishing diets. 
Bessa et al. [44] and Madeira et al. [35] represented no significant differences in MUFA as CP levels were decreased by $3 \%-4 \%$ in growing-finishing pig diets. The discrepancy between this study and previous studies may due to the high $\mathrm{CP}$ level in our study. In summary, this experiment showed that $13.82 \mathrm{MJ} / \mathrm{kg}$ of $\mathrm{ME}$ in a growing-finishing pig diet can improve fatty acids composition of pork.

The change in $\mathrm{pH}$ after slaughter is a very important factor affecting the freshness, tenderness, color, texture, and storage of pork. In this study, there were no significant differences in $\mathrm{pH}$ at 0 and 24 hours after slaughter (Table 11). This result is in accordance with Apple et al. [18], Widmer et al. [36], Prandini et al. [45], and Madeira et al. [35] who reported that the $\mathrm{pH}$ at 0 and 24 hours after slaughter were not affected by ME (14.57-13.82 MJ/kg and
Dietary energy and crude protein on growth and carcass in pigs

15.49-13.82 J/kg) or CP level (17.7\%-14.5\% and 16\%-13\%).

Meat color results are shown in Table 12. There were no significant differences in $\mathrm{L}^{*}, \mathrm{a}^{*}$, or $\mathrm{b}^{*}$ values as ME level was decreased by $0.42 \mathrm{MJ} / \mathrm{kg}$ or $\mathrm{CP}$ concentration was decreased by $2 \%$. Apple et al. [18] and Hinson et al. [47] also demonstrated that decreasing energy level in the diet did not affect meat color (14.57-13.82 MJ/ $\mathrm{kg} \mathrm{ME}$ and 14.65-13.40 MJ/kg ME, respectively). In addition, Prandini et al. [45] and Madeira et al. [35] represented that decreasing CP level in diet did not affect meat color (17.7\%-14.5\% and $16 \%-13 \%$, respectively).

\section{Conclusions}

An $\mathrm{ME}$ of $13.82 \mathrm{MJ} / \mathrm{kg}$ in growing-finishing pig diets increased

Table 11. Effect of dietary energy and crude protein levels on the $\mathrm{pH}$ of longissimus muscles from growing-finishing pigs

\begin{tabular}{|c|c|c|c|c|c|c|c|c|c|c|}
\hline \multirow{2}{*}{$\begin{array}{l}\text { Energy } \\
\text { CP (\%) }\end{array}$} & \multicolumn{3}{|c|}{ ME $13.40 \mathrm{MJ} / \mathrm{kg}$} & \multicolumn{3}{|c|}{ ME $13.82 \mathrm{MJ} / \mathrm{kg}$} & \multirow{2}{*}{ SEM } & \multicolumn{3}{|c|}{$p$-value } \\
\hline & High & Middle & Low & High & Middle & Low & & ME & $\mathrm{CP}$ & $M \times C$ \\
\hline \multicolumn{11}{|l|}{$\mathrm{pH}$} \\
\hline 0 hours & 6.05 & 6.05 & 6.11 & 6.14 & 6.07 & 5.84 & 0.040 & 0.21 & 0.45 & 0.16 \\
\hline 3 hours & 5.64 & 5.75 & 5.68 & 5.70 & 5.66 & 5.51 & 0.030 & 0.22 & 0.31 & 0.27 \\
\hline 6 hours & 5.58 & 5.64 & 5.58 & 5.56 & 5.54 & 5.51 & 0.016 & 0.08 & 0.49 & 0.59 \\
\hline 12 hours & 5.62 & 5.62 & 5.62 & 5.62 & 5.58 & 5.62 & 0.019 & 0.72 & 0.87 & 0.90 \\
\hline 24 hours & 5.60 & 5.64 & 5.60 & 5.63 & 5.59 & 5.66 & 0.016 & 0.74 & 0.93 & 0.42 \\
\hline
\end{tabular}

$\mathrm{CP}$, crude protein; ME, metabolizable energy; SEM, standard error of the mean.

Table 12. Effect of dietary energy and crude protein levels on color of longissimus muscles from growing-finishing pigs

\begin{tabular}{|c|c|c|c|c|c|c|c|c|c|c|}
\hline \multirow{2}{*}{$\begin{array}{l}\text { Energy } \\
\mathrm{CP}(\%)\end{array}$} & \multicolumn{3}{|c|}{ ME $13.40 \mathrm{MJ} / \mathrm{kg}$} & \multicolumn{3}{|c|}{ ME $13.82 \mathrm{MJ} / \mathrm{kg}$} & \multirow{2}{*}{ SEM } & \multicolumn{3}{|c|}{$p$-value } \\
\hline & High & Middle & Low & High & Middle & Low & & ME & $\mathrm{CP}$ & $M \times C$ \\
\hline \multicolumn{11}{|l|}{$\mathrm{CIE}$ value, $\mathrm{L}^{*}$} \\
\hline 0 hours & 39.34 & 38.93 & 38.88 & 40.72 & 39.21 & 39.61 & 0.356 & 0.30 & 0.55 & 0.84 \\
\hline 3 hours & 39.53 & 40.19 & 39.97 & 39.69 & 38.43 & 40.11 & 0.392 & 0.86 & 0.95 & 0.38 \\
\hline 6 hours & 40.73 & 40.38 & 40.07 & 41.07 & 40.86 & 42.14 & 0.515 & 0.40 & 0.94 & 0.78 \\
\hline 12 hours & 43.97 & 41.76 & 43.02 & 43.38 & 43.39 & 44.34 & 0.434 & 0.40 & 0.53 & 0.57 \\
\hline 24 hours & 44.89 & 45.82 & 45.11 & 46.08 & 45.53 & 44.54 & 0.367 & 0.89 & 0.66 & 0.63 \\
\hline \multicolumn{11}{|l|}{ CIE value, $a^{*}$} \\
\hline 0 hours & 1.83 & 1.22 & 1.73 & 1.54 & 1.93 & 1.87 & 0.101 & 0.35 & 0.66 & 0.15 \\
\hline 3 hours & 1.87 & 1.89 & 2.48 & 2.41 & 2.18 & 2.40 & 0.120 & 0.31 & 0.39 & 0.58 \\
\hline 6 hours & 2.06 & 2.18 & 2.86 & 2.78 & 2.43 & 2.70 & 0.123 & 0.28 & 0.26 & 0.35 \\
\hline 12 hours & 3.14 & 2.56 & 3.42 & 3.23 & 3.01 & 3.21 & 0.105 & 0.60 & 0.11 & 0.43 \\
\hline 24 hours & 4.11 & 3.73 & 4.26 & 4.20 & 4.37 & 4.13 & 0.132 & 0.49 & 0.92 & 0.53 \\
\hline \multicolumn{11}{|l|}{ CIE value, $b^{*}$} \\
\hline 0 hours & 4.30 & 3.66 & 3.90 & 4.12 & 4.17 & 4.02 & 0.083 & 0.36 & 0.29 & 0.24 \\
\hline 3 hours & 4.36 & 4.55 & 4.54 & 4.72 & 4.29 & 4.54 & 0.095 & 0.89 & 0.86 & 0.47 \\
\hline 6 hours & 4.64 & 4.57 & 4.93 & 5.22 & 4.70 & 5.10 & 0.127 & 0.28 & 0.48 & 0.74 \\
\hline 12 hours & 5.60 & 5.15 & 5.76 & 5.65 & 5.48 & 5.93 & 0.103 & 0.38 & 0.14 & 0.86 \\
\hline 24 hours & 6.34 & 6.12 & 6.59 & 6.71 & 6.70 & 6.37 & 0.121 & 0.42 & 0.98 & 0.51 \\
\hline
\end{tabular}

$\mathrm{CP}$, crude protein; ME, metabolizable energy; SEM, standard error of the mean. 
the G:F ratio over the entire experimental period, SFA concentration in the longissimus muscles and blood total protein level in the finishing period, while decreasing BUN concentration during the growing period.

When $\mathrm{CP}$ level was decreased in growing-finishing pig diets, blood total protein during the growing phase and BUN during the finishing period were decreased, but MUFA level tended to increase.

In summary, a growing-finishing diet of $13.82 \mathrm{MJ} / \mathrm{kg} \mathrm{ME}$ with the high CP level (18\%/16.3\%/15.3\%/13.2\%) can improve growth performance and show better fatty acids composition of pork.

\section{Competing interests}

No potential conflict of interest relevant to this article was reported.

\section{Funding sources}

This work was carried out with the support of the Cooperative Research Program for Agriculture Science \& Technology Development (Project No. PJ011617), Rural Development Administration, Korea.

\section{Acknowledgements}

Not applicable.

\section{Availability of data and material}

Upon reasonable request, the datasets of this study can be available from the corresponding author.

\section{Authors' contributions}

Conceptualization: Kim YY.

Data curation: Fang LH, Han TH.

Formal analysis: Fang LH, Kim BO.

Methodology: Han TH, Jin YH.

Software: Kim BO, Do SH.

Validation: Jin YH, Hong JS.

Investigation: Kim YY, Hong JS.

Writing- original draft: Fang LH, Do SH.

Writing- review \& deiting: Kim YY, Hong JS.

\section{Ethics approval and consent to participate}

All experimental procedures involving animals were conducted in accordance with the Animal Experimental Guidelines provided by the Seoul National University Institutional Animal Care and Use Committee (SNUIACUC; SNU-160819-9).

\section{ORCID}

Lin Hu Fang

https://orcid.org/0000-0002-3617-7583

Ying Hai Jin
Sung Ho Do

Jin Su Hong

Byung Ock Kim

Tae Hee Han

Yoo Yong Kim

\section{References}

1. Jongbloed AW, Lenis NP. Alteration of nutrition as a means to reduce environmental pollution by pigs. Livestock Prod Sci. 1992;31:75-94.

2. Paik IK, Blair R, Jacob J. Strategies to reduce environmental pollution from animal manure: principles and nutritional management: a review. Asian-Aust.J Anim Sci. 1996;9:615-36.

3. Jeong TS, Heo PS, Lee GY, Kim DH, Ju WS, Kim YY. The influence of phase feeding methods on growth performance, meat quality, and production cost in growing-finishing pigs. J Anim Sci Tech. 2010;52:29-36.

4. Nieto R, Lara L, Barea R, Garca-Valverde R, Aguinaga MA, Conde-Aguilera JA, et al. Response analysis of the Iberian pig growing from birth to $150 \mathrm{~kg}$ body weight to changes in protein and energy supply.J Anim Sci. 2012;90:3809-20.

5. NRC [National Research Council]. Nutrient requirements of swine. 10th ed. Washington, DC, USA: National Academy Press; 1998.

6. NRC [National Research Council]. Nutrient requirements of swine. 11th ed. Washington, DC, USA: National Academy Press; 2012.

7. Buttery PJ, Boorman KN. The energy efficiency of amino acid metabolism. In: Cole DJA, editor. Protein metabolism and nutrition. London: Butterworths; 1976. p.197.

8. Noblet J, Henry Y, Dubois S. Effect of amino acid balance on nutrient utilization and carcass composition of growing swine. J Anim Sci. 1987;65:717-26.

9. Le Bellego L, van Milgen J, Dubois S, Noblet J. Energy utilization of low-protein diets in growing pigs. J Anim Sci. 2001;79:1259-71.

10. Kerr BJ, Southern LL, Bidner TD, Friesen KG, Easter RA. Influence of dietary protein level, amino acid supplementation, and dietary energy levels on growing-finishing pig performance and carcass composition.J Anim Sci. 2003;81:3075-87.

11. Chadd SA, Cole DJA. The performance response of growing and finishing pigs fed differing proportions oat feed as a dietary fiber source. EAAP Annual Meeting; Zurich. 1991.

12. Smith JW 2nd, Tokach MD, O'Quinn PR, Nelssen JL, Goodband RD. Effects of dietary energy density and lysine: calorie ratio on growth performance and carcass characteristics of growing-finishing pigs.J Anim Sci. 1999;77:3007-15. 
13. De la Llata M, Dritz SS, Tokach MD, Goddband RD, Nelssen JL, Loughin TM. Effects of dietary fat on growth performance and carcass characteristics of growing-finishing pigs reared in a commercial environment. J Anim Sci. 2001;79:2643-50.

14. Lopez J, Goodband RD, Allee GL, Jesse GW, Nelssen LJ, Tokach MD, et al. The effects of diets formulated on an ideal protein basis on growth performance, carcass characteristics, and thermal balance of finishing gilts housed in a hot, diurnal environment. J Anim Sci. 1994;72:367-79.

15. Kerr BJ, Easter RA. Effect of feeding reduced protein, amino acid-supplemented diets on nitrogen and energy balance in grower pigs. J Anim Sci. 1995;73:3000-8.

16. Whittemore CT. The science and practice of pig production. London, UK: Longman Scientific \& Technical; 1998. p.661.

17. Schinckel AP, de Lange CF. Characterization of growth parameters needed as inputs for pig growth models. J Anim Sci. 1996;74:2021-36.

18. Apple JK, Maxwell CV, Brown DC, Friesen KG, Musser RE, Johnson ZB, et al. Effects of dietary lysine and energy density on performance and carcass characteristics of finishing pigs fed ractopamine. J Anim Sci. 2004;82:3277-87.

19. Kim BG, Lindemann MD. A spreadsheet method for the experimental animal allotment.J Amin Sci. 2007;85:112.

20. AOAC. Official methods of analysis. 16th ed. Washington, DC, USA: Association of Official Analytical Chemist; 1995.

21. Folch J, Lees M, Sloane-Stanley GH. A simple method for the isolation and purification of total lipides from animal tissues.J Biol Chem. 1957;226:497-509.

22. Jin CF, Kim JH, Han IK, Bea SH. Effects of supplemental synthetic amino acids to the low protein diets on the performance of growing pigs. Asian-Australas J Anim Sci. 1998;11:1-7.

23. Edmonds MS, Baker DH. Effect of dietary protein fluctuations and space allocation on performance and carcass quality of growing-finishing pigs.J Anim Sci. 2003;81:2783-91.

24. Kil DY, Ji F, Stewart LL, Hinson RB, Beaulieu AD, Allee GL, et al. Effects of dietary soybean oil on pig growth performance, retention of protein, lipids, and energy, and the net energy of corn in diets fed to growing or finishing pigs. J Anim Sci. 2013;91:3283-90.

25. Bergner H. Protein evaluation and protein metabolism. In: Adler-Nissen J, Eggum BO, Munck L, editors. Biochemical aspects of new protein food. FEBS 11th Meeting. Copenhagen, Danmark: Pergamon Press; 1977.p.149-60.

26. Hahn JD, Gahl MJ, Giesemann MA, Holsgraefe DP, Fodge DW. Diet type and feed form effects on the performance of finishing swine fed the $\beta$-mannanase enzyme product Hemi-
cell.J Anim Sci 1995;73 Suppl 1:75.

27. Hatori $Y$, Noguchi G, Itoh M, Ishibashi T. Effects of dietary protein levels on performance, plasma amino acid concentrations and biochemical components of female growing pigs. Anim Sci Tech. 1994;65:942-9.

28. Coma J, Zimmerman DR, Carrion D. Lysine requirement of the lactating sow determined by using plasma urea nitrogen as a rapid response criterion.J Anim Sci. 1996;74:1056-62.

29. Fuller MF, Weekes TE, Cadenhead A, Bruce JB. The protein-sparing effect of carbohydrate. 2. The role of insulin. $\mathrm{Br} \mathrm{J}$ Nutr. 1977;38:489-96.

30. Whang KY, Easter RA. Blood urea nitrogen as an index of feed efficiency and lean growth potential in growing-finishing swine. Asian-Australas J Anim Sci. 2000;13:811-6.

31. Bergsjo B, Langseth W, Nafstad I, Jansen JH, Larsen HJ. The effects of naturally deoxynivalenol-contaminated oats on the clinical condition, blood parameters, performance and carcass composition of growing pigs. Vet Res Commun. 1993;17:28394.

32. Matthews JO, Gentry LR, Chapa AM, Higbie AD, Southern LL, Fernandez LM, et al. Changes in plasma metabolites and hormones in pigs relative to time of feeding. J Anim Sci. 1998;76 Suppl 1:168.

33. Kil DY,Ji F, Stewart LL, Hinson RB, Beaulieu AD, Allee GL, et al. Net energy of soybean oil and choice white grease in diets fed to growing and finishing pigs. J Anim Sci. 2011;89:44859.

34. Stewart LL, Kil DY, Ji F, Hinson RB, Beaulieu AD, Allee GL, et al. Effects of dietary soybean hulls and wheat middlings on body composition, nutrient and energy retention, and the net energy of diets and ingredients fed to growing and finishing pigs. J Anim Sci. 2013;91:2756-65.

35. Madeira MS, Alfaia CM, Costa P, Lopes PA, Lemos JP, Bessa $\mathrm{RJ}$, et al. The combination of arginine and leucine supplementation of reduced crude protein diets for boars increases eating quality of pork.J Anim Sci. 2014;92:2030-40.

36. Widmer MR, McGinnis LM, Wulf DM, Stein HH. Effects of feeding distillers dried grains with solubles, high-protein distillers dried grains, and corn germ to growing-finishing pigs on pig performance, carcass quality, and the palatability of pork. J Anim Sci. 2008;86:1819-31.

37. Meng QW, Yan L, Ao X, Zhou TX, Wang JP, Lee JH, et al. Influence of probiotics in different energy and nutrient density diets on growth performance, nutrient digestibility, meat quality, and blood characteristics in growing-finishing pigs.J Anim Sci. 2010;88:3320-6.

38. Madsen A, Jakobsen K, Mortensen HP. Influence of dietary fat on carcass fat quality in pigs. A review. Acta Agric Scand. 
1992;42:220-5.

39. EFSA [European Food Safety Authority]. Scientific opinion on dietary reference values for fats, including saturated fatty acids, polyunsaturated fatty acids, monounsaturated fatty acids, trans fatty acids, and cholesterol. EFSA J. 2010;8:1461.

40. Teye GA, Sheard PR, Whittington FM, Nute GR, Stewart A, Wood JD. Influence of dietary oils and protein level on pork quality. 1. Effects on muscle fatty acid composition, carcass, meat and eating quality. Meat Sci. 2006;73:157-65.

41. Wood JD, Lambe NR, Walling GA, Whitney H, Jagger S, Fullarton PJ, et al. Effects of low protein diets on pigs with a lean genotype. 1 . Carcass composition measured by dissection and muscle fatty acid composition. Meat Sci. 2013;95:123-8.

42. Nemechek JE, Tokach MD, Dritz SS, Goodband RD, DeRouchey JM, Woodworth JC. Effects of diet form and type on growth performance, carcass yield, and iodine value of finishing pigs. J Anim Sci. 2015;93:4486-99.

43. Davis JM, Urrioal PE, Shurson GC, Baidoo SK, Johnston LJ.
Effects of adding supplemental tallow to diets containing 30\% distillers dried grains with solubles on growth performance, carcass characteristics, and pork fat quality in growing-finishing pigs. J Anim Sci. 2015;93:266-77.

44. Bessa RJ, Hughes RA, Jeronimo E, Moreira OC, Prates JA, Doran O. Effect of pig breed and dietary protein level on selected fatty acids and stearoyl-coenzyme a desaturase protein expression in longissimus muscle and subcutaneous fat.J Anim Sci. 2013;91:4540-6.

45. Prandini A, Sigolo S, Morlacchini M, Grilli E, Fiorentini L. Microencapsulated lysine and low-protein diets: effects on performance, carcass characteristics and nitrogen excretion in heavy growing-finishing pigs. J Anim Sci. 2013;91:4226-234.

46. Hinson RB, Wiegand BR, Ritter JM, Allee LG, Carr SN. Impact of dietary energy level and ractopamine on growth performance, carcass characteristics, and meat quality of finishing pigs.J Anim Sci. 2011;89:3572-9. 